\title{
Sınıf Öğretmenlerinin Yabancı Uyruklu Öğrencilere İlişkin Sorunları ile Çözüm Önerilerinin Değerlendirilmesi
}

\author{
Doç. Dr. Nihal YILDIZ-YILMAZ* \\ Karamanoğlu Mehmetbey Üniversitesi, Eğitim Fakültesi, Temel Eğitim Bölümü, Karaman / Türkiye, \\ nihalyildizyilmaz@gmail.com, ORCID: 0000-0002-6840-1594

\section{Erdal DEMIR} \\ Abdurrahim Karakoç İlkokulu, Karaman / Türkiye, \\ erdaldemir972@hotmail.com, ORCID: 0000-0001-8815-086
}

\section{$\ddot{O} z$}

Bu araştırmanın amacını, sınıf öğretmenlerinin yabancı uyruklu öğrencilere ilişkin yaşadıkları problemler ile bu problemlere getirdikleri çözüm önerilerinin değerlendirilmesi oluşturmaktadır. Araştırmada, nitel araştırma yöntemlerinden olgubilim (fenomoloji) deseni kullanılmıştır. Çalışma grubu, 2018-2019 eğitim öğretim yılında öğretmenlik yapmaya devam eden 35 öğretmenden oluşmaktadır. Örneklem seçiminde amaçlı örneklem yöntemlerinden ölçüt örneklem yöntemi seçilmiştir. Ölçüt olarak ise 2018-2019 eğitim öğretim yılı içerisinde sınıfında en az 1 tane yabancı uyruklu öğrenci olması olarak belirlenmiştir. Verilerin toplanmasında amaca uygun olarak araştırmacılar tarafından geliştirilen yarı yapılandırılmış görüşme formu kullanılmıştır. Verilerin analizinde içerik analizi uygulanmıştır. İçerik analizine uygun olarak kodlamalar yapılmış ve temalar oluşturulmuştur. Araştırma sonuçlarına göre, öğretmenler sınıflarında en az 1, en fazla 5 yabancı uyruklu öğrenci bulunmasına karşın, büyük bir 
bölümü Milli Eğitim Bakanlığı'nın yabancı uyruklu öğrenciler için herhangi bir çalışma yapmadığını, bunun yanında kendilerinin de sınıf ortamında yabancı uyruklu öğrencilere yönelik olarak herhangi bir farklılık yapmadıklarını belirtmişlerdir. Ayrıca, öğretmenlerin bu öğrencilerle ilgili yeterli eğitim almadıkları veya herhangi bir eğitim almadıkları tespit edilmiştir. Bu durum, öğretmenlerin yabancı uyruklu öğrencilerle ilgili olarak ortaya çıkan sorunların çözümü konusunda herhangi bir fikir verememesine neden olmaktadır. Öğretmenler, öğrencilerin herhangi bir eğitim sürecine dâhil olmadan doğrudan eğitime dâhil olmaları ile birlikte çok ciddi bir dil, uyum ve iletişim sorunuyla karşı karşıya kalmaktadırlar.

Anahtar Kelimeler: Yabancı uyruklu öğrenciler; Sınıf öğretmenleri; Problemler; Çözüm önerileri.

\title{
Evaluation of Classroom Teachers' Problems Related to Foreign Students and Suggestions for Solutions
}

\begin{abstract}
The aim of this study is to evaluate the problems faced by the classroom teachers regarding foreign students and their solution suggestions for these problems. A case study has been used among qualitative research methods in the research. In the study group of the research, there are 35 class teachers who still have been working in various schools in the city center of Karaman in 2017-2018 academic year. In the selection of the study group, the criterion sampling method among purpose sampling methods has been used. The main criterion in this study has been determined as the presence of at least one foreign student in the class of the research participants. A semi-structured interview form has been prepared as data collection tool. In the research, content analysis, which is one of the qualitative data analyzes, has been used. According to the findings of the study, various results have been reached. Although there are foreign students at least 1 at most 5 students in the teachers' classrooms, it has been determined that teachers have not received sufficient or any education about these students. This situation causes teachers are not able to make any idea about solving the problems that arise in relation to foreign students. Together with the students are directly involved in the education level without being involved in any educational process, their results are faced with a very serious language, harmony and communication problem arise.
\end{abstract}

Keywords: Foreign students; Primary school teachers; Problems; Solution offers. 


\section{Extended Summary}

\section{Purpose}

The aim of this study is to evaluate the problems faced by the classroom teachers regarding foreign students and their solution suggestions for these problems.

\section{Method}

A case study has been used among qualitative research methods in the research. In the study group of the research, there are 35 class teachers who still have been working in various schools in the city centre of Karaman in 2017-2018 academic year. In the selection of the study group, the criterion sampling method among purpose sampling methods has been used. The main criterion in this study has been determined as the presence of at least one foreign student in the class of the research participants. A semi-structured interview form has been prepared as data collection tool. The interview form has consisted of two parts. In the first part, personal information form has been formed in order to obtain personal information of class teachers. In the second section, questions have been prepared for the problems and solution suggestions of class teachers about foreign students. In the research, content analysis, which is one of the qualitative data analyses, has been used. Encodings have been done in accordance with the content analysis and themes have been created in accordance with the given answers. In order to ensure reliability in the research, two procedures have been performed. First, the data that can represent each category in the findings have been given directly without any comment. The second procedure has been to apply to expert opinion in order to determine whether the expressions under the 58 conceptual categories reached in the study represent the category in question. The reliability of the study has been calculated as $98.9 \%$ with the formula of Miles and Huberman (1994).

\section{Results}

According to the findings of the study, it has been determined that more than half of class teachers have joined the education such as courses and seminars intended to the teaching of foreign students. The problem of language and the problem of communication with the student come at the beginning of the problems experienced with foreign students. The majority of class teachers think that the Ministry of National Education does not make any studies in the fields such as programs and book activities related to foreign students. Also, more than half of class teachers have pointed out that they did not organize 
their classes according to foreign students. Language and communication that are similar to the problems experienced with the students have been pointed out that among the biggest problems experienced by the families of foreign students and classroom teachers. Among the needed suggestions of class teachers about the foreign students, included in their classes by opening a separate class and teaching Turkish in advance take first place.

\section{Discussion}

The results of the studies conducted by Yavuz and Mizrak (2016) and the studies conducted by Bulut, Kanat-Soysal and Gülçiçek (2018) and the results of the search such as language and financial inability support each other. In the study conducted by Aykırı (2017) they support each other in terms of not getting education of the teachers but they don't support each other in establishing positive relations with the students and the teachers. The results of the study by Göktuna-Yaylacı, Serpil and Yaylacı (2017) and the results of this study do not coincide with the point of taking positive steps in education.

\section{Conclusion}

According to the findings of the study, various results have been reached. Although there are foreign students at least 1 at most 5 students in the teachers' classrooms, it has been determined that teachers have not received sufficient or any education about these students. This situation causes teachers are not able to make any idea about solving the problems that arise in relation to foreign students. Together with the students are directly involved in the education level without being involved in any educational process, their results are faced with a very serious language, harmony and communication problem arise. Almost all teachers agree that there is no study conducted by the Ministry of National Education for these students included in the education system. The fact that the Ministry of Education does not carry out a study in books, programs or activities still returns to class teachers as a problem. Because they do not have an idea and solution suggestion related to include foreign nationals to the activities in the normal books and in the program. With Institutions do not make any arrangements and do not make any suggestions, most of the class teachers cause them not to do any work for their foreign students in their class due to being unsolved. Classroom teachers also have a language and communication problem with their parents as much as the students. The number of teachers who say that I do not have problems is almost little. Considering the solution suggestions of teachers about foreign students, 
it is remarkable that teachers think that a separate class for these students should be opened. This is an indication that they do not want students in their classrooms without knowing Turkish. The most remarkable point is that almost all of the suggestions are for students and the Ministry of National Education in numerous solutions. The fact that only 3 people make suggestions about the teachers can be considered as an indication that the teachers are far from self-criticism.

\section{Giriş}

İnsanlık tarihi boyunca çeşitli sebeplerle bölgeler arası herhangi bir sebeple ya da herhangi bir sebep olmaksızın göçler yaşanmaktadır. Yaşanan bu yer değiştirmeler hem göç edenleri hem de göçmen olarak gidilen bölgeleri doğrudan ya da dolaylı olarak etkilemektedir. Ancak bu etkiden elbette diğer tüm olaylarda olduğu gibi en fazla etkilenenler arasında çocuklar yer almaktadır. Çevreleri, dilleri, akran ilişkileri en önemlisi de eğitimleri farklılaşmaktadır. Bu farklılaşma göçmen çocukların etkileşim içinde olduğu akranlarını ve öğretmenlerini doğrudan etkilemektedir.

Fertlerin üzerindeki yaşadıkları toprakları terk etmelerine sebep olacak birçok neden vardır. Göç nedenleri olarak görülebilecek etkenleri; iktisadi yetersizlikler, çevresel bozulmalar, nüfus sorunları, eğitimde yaşanan sıkıntılar, siyasi ve ideolojik sorunlar ve savaşlar şeklinde sıralanabilir (Kaştan, 2015; Sarıtaş, Şahin ve Çatalbaş, 2016). Göç olayları değişik şekillerde oluşmaktadır. Bu durum bazen ülke içerisinde gerçekleștiği gibi bazen de ülkeler arası hatta kıtalara arası da gerçekleşebilmektedir (Özdemir, Benzer ve Akbaş, 2009). Bu değişimler ferdi olduğu gibi kitleler halinde de olmaktadır (Şahin, 2001). Kitlesel göç, toplumun tüm kesimince etkileri görülen iktisadi ve sosyal olayların neticesinde meydana gelen göç olayıdır (Sezik ve Ağır, 2015; Şimşir ve Dilmaç, 2018). Kitlesel göç olayları tetikleyen en önemli öge savaşlardır. Uzun ve şiddetli bir şekilde süren bu savaşlar insanları yaşadıkları yerlerden göç etmeye zorlamaktadır. Kitlesel göç olayları iki unsura bağlı olarak zorunlu göç kapsamında görülmektedir: Birincisi ülke nüfusunun asgari olarak \%1'lik bölümünün can güvenliği sorunuyla karşılaşmasıdır. İkinci olarak da 100 bin insanın hayat şartlarının oldukça kötü durumda olması veya mecburiyetten dolayı topraklarını bırakmak zorunda kalmış olmalarıdır (Boyraz, 2015; Dinçer, Karaca ve Yavuz, 2013; Şimşir ve Dilmaç, 2018). Günümüzde Irak ve Suriye gibi ülkelerden gerçekleşen göçler mecburi ve kitlesel diş göçler olarak görülmektedir (Sezik ve A ğır, 2015; Şimşir ve Dilmaç, 2018). 
“Dünya genelinde hemen hemen her ülke göçten etkilenmiştir. Özellikle 20. yüzyllın ikinci yarısında toplu nüfus hareketlerine şahitlik edilmiş, göçmen nüfusu son yarım yüzyılda hızlı bir artış göstermiştir. Nitekim Birleşmiş Milletler verilerine göre son 20 yıldaki hızıyla artmaya devam ederse, dünyadaki uluslararası göçmenlerin sayısının 2050'de 405 milyona ulaşması beklenmektedir. Bu anlamda; Cumhuriyet döneminde 1922-1945 yillar arasinda Yunanistan, Balkanlar ve Almanya'dan yaklaşık 1 milyon 185 bin kişinin Türkiye'ye gelmiştir. 1988-2000 yılları arasında Irak, Bulgaristan, Bosna ve Kosova'dan yaklaşık 900 bin kişinin gelmesi Türkiye'nin mevcut göç tarihinin en somut örnekleri arasında yer almış, özetle Türkiye milyonlarca kişiye ev sahipliği yapmıştır.” (2016 Göç Raporu, 2017, s.23).

Mevcut koşullar ve küreselleşme gibi sebepler toplumları birbirine yaklaştırmış ve etkileşimleri arttırmıştır. Bununla birlikte Türkiye'nin ekonomik yönden bir çekim merkezi haline gelmesi, etrafındaki komşu ülkelerde cereyan eden iç savaşlar gibi nedenlere bağlı olarak farklı din ve etnik kökene mensup pek çok insanın ülkemize göç etmesine sebep olmuştur (Başak, 2011; Güngör ve Şenel, 2015). Fert ve toplum arasında tarih boyunca devam edegelen bir etkileşim mevcuttur. Küreselleşme neticesinde kültürel ve sosyal yönden iletişim olanakları üst seviyede gerçekleşmektedir. Bu gelişme de bir yandan çok türlülüğü diğer yandan da kültürel benzeşmeyi beraberinde getirecektir (Çalık ve Sezgin, 2015; Güngör ve Şenel, 2015).

Türkiye, coğrafi konumu nedeniyle göçmenlere kapılarını açan, ihtiyaç sahiplerini koruma altına alan ve dünya kamuoyunca da saygı duyulan bin yıllık köklü bir göç geleneğine sahiplik etmiştir.

Türkiye’ye göçlerin hızlanmasında en önemli etmenlerden biri de Suriye'de 2010 yılında başlayan iç savaştır. Emniyet ve güvenlik gerekçesiyle insanlar Türkiye, Lübnan, Mısır, Ürdün gibi ülkelere sığınmacı olarak yerleşmişlerdir. Bu ülkeler arasında Türkiye'de Suriyeli göçmen barınmaktadır (Afet ve Acil Durum Yönetimi Başkanlığı [AFAD], 2017). Kasım 2017 yılı itibarıyla Birleşmiş Milletler Mülteciler Yüksek Komiserliği'nin verilerine göre 5.379.644 Suriyeli, mülteci durumundadır. Bunlardan 3 milyonu Türkiye'de, 2 milyonu Ürdün, Lübnan, Irak ve Misır'da; az bir kısmı da Kuzey Afrika' da hayatlarına devam etmektedir (UNHCR, 2017a).

Göçler her şartta yerleşik olan kültürden uzaklaşma, farklı bir dil, farklı bir kültür, farklı bir ortamla yüz yüze gelme olduğu için sorun teşkil etmekte, fertlerde uyum sorunları oluşturmaktadır (Kılınç, 2014; Özdemir, Benzer, Akbaş, 2009; Uluocak, 2009). İç ve diş göçler için de mevcut durum geçerlidir. 
Fakat dış göçlerde kültürel farklılık ve ayrışmalar daha sık yaşandığı için sorunlar da çoğalmaktadır (Özdemir, Benzer ve Akbaş, 2009, 24). Meydana gelen problemlerin içinde en büyük sorun eğitim öğretimle alakalı olanıdır. Eğitim bir toplumun en esaslı sosyal ihtiyaçlarından biridir.

Göç raporu Türkiye'nin ve göçmenlerin en önemli yaşadıkları sorunlardan biri de eğitim sorunudur. Gelenlerin \%54 bir oranla (1.471.958) çocuk (Birleşmiş Milletler Çocuklara Yardım Fonu [UNICEF], 2016) ölümü gerçekleştiği hesaba katılırsa bu konunun ne kadar önemli olduğu bir kez daha ortaya çıkmaktadır. Nitekim bu çocukların 500.000'i eğitim imkânlarından faydalanamamaktadır (UNICEF, 2016). Uluslararası sözleşmeler nedeni ile Türkiye yabancı uyruklu öğrenciler dâhil tüm çocuklara eğitim verme zorunluluğunu üstlenmiştir. $\mathrm{Bu}$ durum gerekli ölçüde çözüm bulunmaması halinde ileride daha büyük sorunların ortaya çıkmasına yol açacaktır (Seydi, 2013).

Türk eğitim sistemine her geçen gün artan bir şekilde eğitim-öğretime yabancı uyruklu öğrenciler dâhil olmaktadır. Bu gerçek, kültürler arası iletişimi zorunlu kılmaktadır. Eğitim, bir kültür aktarımı ve iletişimi sağlayan önemli bir araçtır. Bu nedenle eğitim ortamının uygun hale getirilmesi, davranış değişikliğini gerçekleştirmede öğrenciye rehberlik yapılması, hedef konulan davranışlara ne ölçüde ulaşıldığının güvenilir ve sistematik bir şekilde denetlenmesi elzemdir (Uyar, 2007).

Türkiye'de yabancı uyruklu çocukların bulunma ve eğitim görme amaçları değişkenlik arz etmektedir. Bu öğrenciler ülkemizde uygulanan bu eğitim sistemine yaşlarına uygun sınıflara denkliğe göre yerleştiklerinden dolayı hem kendileri hem öğretmenleri hem de ebeveynleri büyük sıkıntılar yaşamaktadır. İletişim ve uyum sorunları bu sorunların en başında yer almaktadır. Bu öğrencilere yönelik ders programları, kaynaklar ve yardımcı kaynakların bulunmayışı; sınıf ortamlarının eğitim düzeyine, ana diline, yaşına ve kültürüne göre hazırlanmayışı, yaşanan sorunlardan en önemlileridir. Ayrıca, istifade edilen yöntem ve materyallerin öğrencilerin beklentilerine karşılık verememesi ve birçok noksanlıkların varlığı önemli bir sorun kaynağı niteliğindedir (Er, Biçer ve Bozkırlı, 2012; Polat, 2012). Eğitim sistemimiz maalesef yabancı uyruklu öğrencilerin eğitim öğretimi alanında yetersiz olduğu öğretmenlerce dile getirilmektedir. Eğitimin, bu öğrencilerin beklentilerine cevap verebilmesi için öncelikle bu öğrencilerin yaşadıkları toplumun dili olan Türkçeyi iyi öğrenmeleri gerekmektedir (Parekh, 2002'den akt; Ar1, 2010).

Eğitim kurumlarında yapılması elzem olan sorunları kaynağında tespit 
edip yaşanabilecek olası sorunların önüne geçebilmektir. Bunun için de; eğitim kurumlarında endirekt veya direk olarak ilgili bulunan herkesin sorunların çözümü noktasında birlikte hareket edebilmesi oldukça elzem olarak görülmektedir (Yapıc1 ve Yapıc1, 2003).

Türkiye'de temel eğitim düzeyinde bu alanda yapılan çalışmalar oldukça azdır ve bu sahada MEB ve devlet politikalarına yön verecek teklif niteliğinde çalışmalar da sığ kalmıştır (Ciğerci ve Güngör, 2016; Er ve ark., 2012; Gürle, 2012; Özer ve ark., 2016; Polat, 2012; Sarıtaş ve ark., 2016).

Tanrıkulu (2017) tarafindan yapılan çalışmada ön plana çıkan sorunlar şu şekilde belirlenmiştir: dil eğitimi, okullarda kayıt sorunu, ara sınıflar, marjinalleşme durumu, geçerli diploma ve eğitim belgesi ihtiyacı, özel eğitime ihtiyaç duyan çocuklar ve rehabilitasyon süreçleri, Türkçe öğretimi ve materyal sıkıntıları, Suriyeli öğretmenlerin durumu, okulu terk etmek, diğer okul seçeneklerini çoğaltmak, kurumlar arası koordinasyon, kültürel farklar ve asimilasyon endişesi, ders içerikleri, uyum meselesi, eğitim sorununa odaklanmak, kültürel etkileşim. Araştırmada da belirtildiği üzere eğitim sorununa odaklanmak Suriyeli sığınmacılar ile ilgili önemli problemler arasında gösterilmektedir.

Ülkemizde yabancı uyruklu öğrenciler ile ilgili Milli Eğitim Bakanlığı çeşitli çalışmalar yapmaktadır. MEB tarafından 2014 yılında yayınlanan Yabancılara Yönelik Eğitim Öğretim Hizmetleri Genelgesi'nde geçici eğitim merkezlerini açıklamıştır (MEB, 2014). Ülkemizde Suriyeli mülteci sayısının artması ile eğitim-öğretim yaşında öğrenci sayısında da artış olmuştur. Resmi rakamlara göre 2018 tarihi itibari ile ülkemizde bulunan Suriyeli mülteci sayıs1 3.593.864'tür. Bu sayının 608.702'si 2017-2018 eğitim öğretim yılında ülkemizde eğitime erişimi sağlanan öğrenci sayısıdır. Mülteci öğrenciler resmi devlet okullarında ve geçici eğitim merkezlerinde öğrenimlerini sürdürmektedirler. Ülkemizde var olan geçici eğitim merkezi sayısı ise 224.457'dir (MEB, 2018). Milli Eğitim Bakanlığı 2019/15 sayılı genelgede Yabancı Öğrenciler Uyum Sınıflarının açılmasını belirtmiştir. Ancak bu genelge ile uyum sınıflarında sadece dil becerisi üzerine odaklanmıştır. Türkçe Yeterlilik Sınavları yapılacağ 1 ve bu sınavlardan 60 altında alanların uyum sınıflarına alınacağı ile bu uyum sınıflarının nasıl oluşturulacağı açıklanmaktadır (MEB, 2019).

$\mathrm{Bu}$ araştırma, yabancı uyruklu öğrencilerin eğitim-öğretimleri sırasında karşılaştıkları sorunların çözülmesinde öğretmenlere yol göstermesi açısından 
önem arz etmektedir. Bununla ilgili sorunlar nasıl çözülebilir? sorusuna cevap aramak için yapılan bu çalışmada okullardaki eğitim öğretim faaliyetlerinden sorumlu olan sınıf öğretmenlerinin göç yoluyla gelen yabancı uyruklu öğrencilerle ilgili yaşadıkları sorunları, sorunlara çözüm önerilerinin neler olduğu araştırılmıştır. Araştırmanın amacı, yabancı uyruklu öğrencilerin eğitim öğretim gördükleri sınıflarda yaşadıkları sorunların sınıf öğretmenleri gözüyle irdelenmesi ve değerlendirilmesidir. Bu genel amaç doğrultusunda, araştırmada şu sorulara yanıt aranmıştır:

1. Sınıf öğretmenlerinin yabancı uyruklu öğrencilerle ilgili yaşadıkları sorunlar genel olarak nelerdir?

2. MEB programlarında, kitaplarında ve uygulamada yabancı uyruklu öğrencilere yönelik ne gibi çalışmalar yapılmıştır?

3. Sınıf öğretmenleri yabancı uyruklu öğrencilere yönelik olarak ne gibi özel çalışmalar yapmaktadırlar?

4. Sınıf öğretmenleri, yabancı uyruklu öğrencilerin aileleriyle iletişimde ne gibi problemler yaşamaktadır?

5. Yabancı uyruklu öğrencilerin sorunlarının çözümü ile ilgili yapılması gerekenler hakkında önerileriniz nelerdir?

\section{Yöntem}

\section{Araștırma Modeli}

Araştırmada nitel araştırma yöntemlerinden olgubilim (fenomoloji) araştırması olarak desenlenmiştir. Olgubilim deseninde çalışmalar katılımc1lar tarafından tanımlanan bir olgu ile ilgili araştırmacının insan deneyimlerini ortaya çıkarmak için uygulanan sorgulama stratejisi olarak tanımlanmaktadır (Creswell, 2013). Olgular içinde bulunduğumuz dünyada olaylar, deneyimler, algılar, yönelimler, kavramlar gibi çeşitli şekillerde karşımıza çıkabilir. Tam anlamını kavrayamadığımız olguları araştırmayı amaçlayan çalışmalar için olgubilim doğru bir araştırma yöntemidir (Yıldırım ve Şimşek, 2006). Olgubilim yaşanan deneyimleri anlamaya çalışır aynı zamanda kalıp ve anlam ilişkileri geliştirmek için kapsamlı ve uzun süreli odaklanma yoluyla az sayıdaki konuyu incelemeyi içeren bir yöntem olarak nitelendirilmektedir (Moustakas, 1994).

\section{Çalışma Grubu}

Araştırmanın çalışma grubunda 2018-2019 eğitim öğretim yılında Karaman merkezde çeşitli okullarda mesleğine halen devam eden 35 tane sınıf öğretmeni oluşturmuştur. Çalışma grubunun seçiminde amaçlı örnekleme 
yöntemlerinden ölçüt örnekleme yöntemi kullanılmıştır. Amaçlı örnekleme yöntemi pek çok durumda, olgu ve olayların keşfedilmesinde, açılanmasında yararlıdır. Ölçüt örneklemede ise önceden araştırmacı tarafından hazırlanan ölçütler dâhilinde bütün durumların çalışılması mevcuttur (Yıldırım ve Şimşek, 2006). Bu araştırmadaki temel ölçüt ise araştırmaya katılan katılımcıların sınıflarında en az 1 tane yabancı uyruklu öğrencinin bulunması olarak belirlenmiştir. Katılımcılara ilişkin demografik bilgiler Tablo 1'de sunulmuştur:

Tablo 1. Katılımcılara İlişkin Demografik Bilgiler

\begin{tabular}{lll}
\hline Demografik Bilgiler & & f \\
\hline Cinsiyet & Kadın & 21 \\
& Erkek & 14 \\
\hline Yaş & $20-25$ yaş & 1 \\
& $26-30$ yaş & 1 \\
& $31-35$ yaş & 7 \\
& 36 ve üstü & 26 \\
\hline Deneyim & $1-5$ yıl & 1 \\
& $6-10$ yıl & 4 \\
& $11-15$ yıl & 4 \\
& $16-20$ yıl & 9 \\
& 21 ve üstü yıl & 17 \\
\hline Yabanc1 Uyruklu & 1 tane & 5 \\
Öğrenci Sayis1 & 2 tane & 12 \\
& 3 tane & 9 \\
& 4 tane & 5 \\
& 5 tane & 4 \\
\hline
\end{tabular}

Tablo 1'e göre öğretmenlerden 21 tanesi kadın, 14 tanesi erkektir. Araştırmanın katılımcılarının Karaman merkezde görev yapmasından dolayı sınıf öğretmenlerinden 26 tanesi 36 ve üstü yaşa sahip olup 21 ve üstü yılda deneyime sahiptirler. Sınıf öğretmenlerinin sınıflarında en az 1 tane, en fazla 5 tane olmak üzere yabancı uyruklu öğrenci bulunmaktadır. Bu sayı daha çok 2 ve üzerinde yabancı uyruklu öğrenci olarak belirlenmiştir.

Araştırmada öğretmenlerin yabancı uyruklu öğrencilerin eğitim-öğretimine yönelik eğitimlere katılma durumu çalışmayı güçlendireceği düşüncesi ile Tablo 2'de sunulmuştur:

Tablo 2. Yabancı Uyruklu Öğrencilerin Eğitim-Öğretimine Yönelik Eğitimlere Kat1lma Durumu

\begin{tabular}{lll}
\hline Eğitimlere Katılma Durumu & f \\
\hline \multirow{3}{*}{ Katıldım } & Seminer & 14 \\
& Kurs & 6 \\
& Uyum Eğitimi & 1 \\
\hline Katılmadım & & 14 \\
\hline Toplam & & 35 \\
\hline
\end{tabular}


Tablo 2 incelendiğinde 21 sınıf öğretmeni yabancı uyruklu öğrencilerle seminer, kurs ve uyum eğitimleri aldıklarını belirtirken 14 sınıf öğretmeni ise hiçbir eğitim almadığını ifade etmiştir. Yabancı uyruklu öğrenciler ile ilgili eğitim aldığını ifade eden 21 sınıf öğretmeninden 14 tanesi 1-2 günlük seminerlere katıldığını belirtirken 6 tanesi yaklaşık 1 haftalık kurslara katıldığını belirtmiş ve 1 tanesi de yabancı uyruklu öğrencileri kabullenmek için uyum eğitimi aldığını belirtmiştir.

\section{Veri Toplama Araçları}

Veri toplama aracı olarak öncelikle alanyazın taranarak kuramsal temel oluşturulmuş ve yarı yapılandırılmış bir görüşme formu hazırlanmıştır. Görüşme formu oluşturulurken katılımcıların olgu ile ilgili algılarını açık ve net bir şekilde belirleyebilmek için Patton (1990) tarafindan belirtilen soru özellikleri doğrultusunda oluşturulmuştur. Bu özellikler; soruların açık net ve anlaşılır olması, birden fazla olmaması, açık uçlu, içerinde yönlendirme olmayan sorulardır. Açık uçlu sorularda nasıl ve niçin gibi sorularla derin bilgiler elde etmek amaçlanmıştır. Bu özellikler doğrultusunda hazırlanan görüşme formu iki bölümden oluşmuştur. Birinci bölümde sınıf öğretmenlerinin kişisel bilgilerini elde etmek amacı ile kişisel bilgi formu oluşturulmuştur. İkinci bölümde ise sınıf öğretmenlerinin yabancı uyruklu öğrencilerle ilgili problemlere ve çözüm önerilerine yönelik olarak sorular hazırlanmıştır. Hazırlanan görüşme formu ile ilgili Necmettin Erbakan Üniversitesi Temel Eğitim Bölümü Sınıf Eğitimi Anabilim Dalı'nda alan uzmanı bir doçent ile bir sınıf öğretmeninin görüşleri alınmıştır. Daha sonra görüşler doğrultusunda soruların anlaş1lırlığı ile ilgili iki soruda anlama yönelik düzenleme yapılmış ve iki sınıf öğretmeni ile pilot uygulama yapılarak forma son hali verilmiştir.

\section{Veri Toplanması ve Analizi}

Sınıf öğretmenlerine yarı yapılandırılmış görüşme formu araştırmacılar tarafindan uygulanmış ve gerekli görülen yerlerde sorulara açıklamalar getirilmiştir. Süreyle ilgili herhangi bir kısıtlamaya gidilmemiş olup ortalama her bir öğretmene 40 dakika yarı yapılandırılmış görüşme formu uygulanmıştır.

Araştırmada nitel veri analizlerinden olan içerik analizi kullanılmıştır. İçerik analizine uygun olarak birinci adımda kodlamalar yapılmış ve ikinci adımda verilen cevaplar doğrultusunda temalar oluşturulmuştur. Üçüncü adımda ise kod ve temalar organize edilmiş ve son olarak dördüncü adımda da bulgular tanımlanmıştır. İçerik analizi yazılı dokümanlar, ses kayıtları, videolar gibi çeşitli iletişim şekillerinin üzerinde yapılan analizler olup analiz 
içeriği araştırma soruları ile ilişkilendirilecek bir veri kodlaması ile başlar (Berg ve Lune, 2015). İçerik analizi belirli kurallarla yapılan kodlamalarla, verilmek istenen mesajın objektif olarak belirlenerek çıkarımların yapıldığg sistematik ve yenilenebilir bir tekniktir (Büyüköztürk, Çakmak, Akgün, Karadeniz ve Demirel, 2009). İçerik analizi yaklaşımında metinlere niteliksel adım olarak kategoriler belirlenir, niceliksel adım olarak ise metinlerin aracılığıyla da kategorilerin sıklı̆̆ 1 ifade edilir (Mayring, 2014). Kodlamalar yap1lırken katılımcının kısaltması şeklinde olan K1, K2, K3 gibi k1saltmalardan yararlanılmıştır.

Araştırmada güvenirliği sağlamak için de iki işlem yapılmıştır. Bunlardan birincisi, bulgularda her kategoriyi temsil edebilecek veriler yorum yapilmadan doğrudan verilmiştir. İkinci işlem ise araştırmada ulaşılan 51 kavramsal kategorinin (dil problemi, MEB'in çalışması yok, sınıf düzenlemesi yapmıyorum, ayrı bir sınıfta ders almaları gibi) altında yer alan ifadeler söz konusu kategoriyi temsil edip etmediğini belirlemek amacı ile uzman görüşüne başvurulmak şeklinde olmuştur. Bu amaç doğrultusunda bir uzmana iki form verilmiştir. Formlardan ilki oluşturulan 51 kavramsal kategoriyi ve özelliklerini içermekteyken, ikincisi 254 adet ifade alfabetik suralı bir şekilde oluşturduğu listeyi içermektedir. Uzmandan bu iki listeyi kullanarak 254 adet ifadeyi oluşturulan 51 kavramsal kategoriyle özelliklerden faydalanarak eşlemesi istenmiştir. Uzman ve araştırmacının yaptığı eşleştirmeler karşılaştırılmıştır. Karşılaştırmalarda belirlenen "görüş birliği" ve "görüş ayrıllğı" sayıları tespit edilmiştir. Araştırmanın güvenirliği Miles ve Huberman'ın (1994) formülü (Güvenirlik=Görüş Birliği/Görüş Birliği+Görüş Ayrılı̆̆ıX100) ile hesaplanmıştır. Uzman ve araştırmacının yaptığı eşleşmelerden "iletişim”, "isteksizlik" ve "uyum" olmak üzere sadece üç ifade birbirinden farklı kategorilerde yer almıştır. Bu durumda, Güvenirlik=254/254+3x100=\%98.8 olarak hesaplanmıştır. Nitel araştırmalarda, uzman ve araştırmacı arasındaki görüş birliği $\% 90$ ve üzeri aralığında olduğu zaman güvenilir olarak kabul edilmektedir (Miles ve Huberman, 1994).

\section{Bulgular}

Araştırmanın temel amacı doğrultusunda her bir alt probleme ait bulgular bu bölümde tablolaştırılarak sunulmuştur. 
"Sınıf Öğretmenlerinin Yabancı Uyruklu Öğrencilerle İlgili Yaşadıkları Sorunlar Nelerdir?" Sorusuna Ait Bulgular

Tablo 3. Sınıf Öğretmenlerinin Yabancı Uyruklu Öğrenciler ile Yaşadığı Problemler

\begin{tabular}{ll}
\hline Yaşanılan Problemler & f \\
\hline Dil problemi & 20 \\
Öğrenci ile iletişim problemi & 16 \\
Uyum problemi & 12 \\
Aile ile iletişim problemi & 5 \\
Devamsızlk problemi & 3 \\
Maddi yetersizlik problemi & 3 \\
Okuma-yazma problemi & 3 \\
Okula karşı isteksizlik & 3 \\
Davranış bozuklukları & 3 \\
Kültür fark1 & 1 \\
Ülke özlemi & 1 \\
Öğretmenin yeterli zaman ayıramama problemi & 1 \\
Tertip düzen problemi & 1 \\
\hline Toplam & 72 \\
\hline
\end{tabular}

1. alt probleme ait olarak sınıf öğretmenleri tarafindan toplam 72 adet yabancı uyruklu öğrenciler ile yaşanılan problem belirlenmiştir. Bunların 13 tanesi aynı kategori altında toplanmıştır. Tablo 3 incelendiğinde yabancı uyruklu öğrenciler ile sınıf öğretmenlerinin yaşadığı en büyük problem 20 adet ile dil problemi olarak belirlenmiştir. Dil probleminin devamı niteliğinde bir diğer problem ise 16 ifade ile öğrenci ile iletişim problemi olarak belirlenmiştir. Bunların dışında çevresine ve arkadaşlarına uyum sorunu, veli ile iletişim sorunu, devamsızlık problemi, maddi yetersizlik problemi, okuma-yazma bilmemelerinden kaynaklı problemler, okula karşı isteksizlik ve davranış bozukluğu gibi problemler de belirtilmiştir. Özellikle 9 kategoride belirtilen problemleri birden fazla öğretmen belirtmiştir. Katılımcıların bazılarının doğrudan ifadeleri şu şekildedir:

"Türkçe bilmeme, iletişim, kültürel farklllıkların yaşattığ problemler, devamsızlık durumu, aileye yeterince ulaşamamak, sinıf içinde yapılan sosyal faaliyet, kermes... vs. de maddi yetersizlik." (K1)

"Yabancı uyruklu öğrencilerin dil ve konuşma problemleri sorun teşkil etmektedir. Söylenenleri tam algllamadiğl ve yorumlayamadiğl için eğitim-öğretim problemleri yaşamaktadır. Ayrica ekonomik olarak stkıntı yaşadıkları için eğitim-ögretim hayatları olumsuz etkilenmektedir." (K10)

"Türkçe bilmedikleri için iletişim kuramıyorum. O beni anlamıyor, ben onu anlamiyorum. Bu yüzden okuma-yazma öğretmekte çok zor oluyor. 
Türkçe bilseler bile, uygulamak zorunda olduğum bir program olduğu

için onlara özel zaman ayıramıyorum." (K19)

"MEB Programlarında, Kitaplarında ve Uygulamada Yabancı Uyruklu Öğrencilere Yönelik Çalışma Yapılmış mıdır? Yapıldıysa Bunlar Nelerdir?" Sorusuna Ait Bulgular

Tablo 4. MEB' in Yabancı Uyruklu Öğrencilere Yönelik Çalışmaların Değerlendirilmesi

\begin{tabular}{ll}
\hline MEB'in Çalışmaları & f \\
\hline MEB'in çalışmaları yok & 24 \\
Bilmiyorum & 5 \\
Kitaplarda var & 3 \\
Türkçe öğrenme sınıfları açıldı & 2 \\
Programlar mevcut & 1 \\
Bazı şehirlerde okullar açıldı & 1 \\
Yapıldığını duydum sadece & 1 \\
\hline Toplam & 31 \\
\hline
\end{tabular}

Sınıf öğretmenlerinin yabancı uyruklu öğrencilere yönelik olarak Milli Eğitim Bakanlığı tarafından yapılan çalışmaları değerlendirmeleri istendiğinde Tablo 4'te de görüldüğü üzere toplam 31 cevap verilmiştir. Verilen cevaplar 7 kategori altında toplanmış olup 4 kategoriye birden fazla öğretmen aynı cevabı vererek dâhil olmuştur. Sadece son 3 kategoriye birer öğretmen cevap vermiştir. Sınıf öğretmenlerinin yarısından fazlası 24 tanesi MEB'in bu konuda bir çalışması olmadığını ifade ederken, 5 tanesi bilmediğini söylemiştir. 6 tane sınıf öğretmeni de 8 tane çalışmadan söz etmiştir. Bunlardan 3 tanesi kitaplarda yabancı uyruklulara yönelik çalışmalar olduğu yönünde iken 2 tanesi Türkçe öğrenme sınıflarının açıldığı şeklinde olmuştur. Katılımcıların bazılarının doğrudan ifadeleri şu şekildedir: "Hayat Bilgisi: Farklı kültürleri tanıma ve iletişim." (K1), "Bu konuda kesinlikle program ve kitaplarda bakanliğın bir hazırlığı söz konusu değildir." (K4), "Türkçe öğrenmeleri için sınıflar açılmıştır." (K17), "Yapıldı̆̆ını sadece duydum. Bize uygulama için herhangi bir şey gelmedi." (K25).

\section{"Sınıf Öğretmenlerinin Yabancı Uyruklu Öğrencilerle İlgili Sınıflarında Yaptıkları Özel Çalışmalar Nelerdir?" Sorusuna Ait Bulgular}

Tablo 5 incelendiğinde sınıf öğretmenlerinin sınıflarında bulunan yabancı uyruklu öğrencilere göre öğrenme ortamını düzenleyip düzenlemediklerine yönelik 8 farklı kategoride 41 ifade kullanmışlardır. 8 farklı kategoriden 5 tanesine birden fazla öğretmen benzer cevabı vermiş olup son 3 kategoriye birer öğretmen cevap vermiştir. Sınıf öğretmenlerinin yarıdan fazlası sınıfta herhangi bir düzenleme yapmadıklarını ifade etmişlerdir. Bunun yanında geri 
kalan 14 kişi ise 20 farklı sınıf düzenlemesi yaptığını belirtmiştir. Bunların içinde ise en çok 10 adet yanıt ile akran eğitimi ortamı oluşturdukları belirlenmiştir. Dil kullanım probleminden dolayı görselleştirmeden yararlandıkları yani resim kullandıklarını belirten 3 tane sınıf öğretmeni mevcuttur. Bunun yanında basit etkinlikler hazırladıklarını belirten 2 sınıf ve ön sırada daha çok iletişime geçildiğinden dolayı orada oturtmayı tercih eden 2'şer sınıf öğretmeni vardır.

Tablo 5. Sınıf Öğretmenlerinin Yabancı Uyruklu Öğrencilere Yönelik Eğitim-Öğretim Ortamı Düzenlemeleri

\begin{tabular}{ll}
\hline Eğitim-Öğretim Ortamı Düzenlemelerinin Değerlendirilmesi & f \\
\hline Sınıf düzenlemesi yapmıyorum & 21 \\
Türk öğrenciler ile yan yana oturtma (akran eğitimi) & 10 \\
Resim kullanma & 3 \\
Basit etkinlikler hazırlama & 2 \\
Ön sırada oturtma & 2 \\
Okul saati dışında okuma-yazma çalışması & 1 \\
Dil gelişimlerini için ortam hazırlama & 1 \\
Bayraklarını asma & 1 \\
\hline Toplam & 41 \\
\hline
\end{tabular}

Katılımcıların bazılarının doğrudan ifadeleri ise şu şekildedir: "Herhangi bir düzenleme yapmadım." (K12), "Kesinlikle onlarında anlayabileceği ve katılabileceği bir sınıf ortamı oluşturmaya çalışıyorum. Yazı tahtasını kullanırken bilmedikleri kavramları resimleştiriyorum." (K18), "Evet, onları diğer ögrencilerle oturtarak sınıf düzenine daha kolay uyum sağlamasını să̆llyorum. Türkçeye hâkimiyetleri bu şekilde biraz daha kolaylaşıyor." (K29).

\section{Sınıf Öğretmenlerinin, Yabancı Uyruklu Öğrencilerin Aileleriyle İleti- şimde Yaşadıkları Problemler Nelerdir?" Sorusuna Ait Bulgular}

Tablo 6 incelendiğinde sınıf öğretmenlerinin velilerle yaşadığı problemlere 35 öğretmenden 50 yanıt gelmiştir. Verilen bu yanıtlar 11 kategori altında toplanmış ve bunlardan 8 tanesine birden fazla öğretmen benzer cevap vermişlerdir. Sadece 3 cevabı birer öğretmen vermiştir. Sınıf öğretmenlerinin yabancı uyruklu öğrencilerin velileri ile yaşadıkları problemlerin değerlendirilmesinde 2 öğretmen hariç diğer öğretmenlerin hepsi problem yaşadıklarından söz etmişlerdir. 2 öğretmen bazen yaşadığını ifade ederken 31 öğretmen 41 adet veli ile ilgili problemden söz etmiştir. Tablo 6 incelendiğinde sınıf öğretmenlerinin velilerle yaşanan problemlerin başında öğrenci ile yaşanılan probleme benzer şekilde 26 kişinin ifadesi ile dil problemi gelmektedir. Bundan sonrada öğrencilerle yine benzer şekilde dil problemi kökenli olarak 
iletişim probleminden 9 adet öğretmen söz etmiştir. Bunların dışında toplantılara katılmama, saygı problemi, ailenin öğrenciye destek vermemesi, düzenli hayatın olmaması gibi problemlerden de söz etmişlerdir.

Tablo 6. Yabancı Uyruklu Öğrencilerin Velileri ile Yaşanılan Problemlerin Değerlendirilmesi

\begin{tabular}{ll}
\hline Velilerle Yaşanılan Problemlerin Değerlendirilmesi & f \\
\hline Dil problemi & 26 \\
İletişim problemi & 9 \\
Kültür fark1 & 2 \\
Toplantılara katılmama & 2 \\
Saygı problemi & 2 \\
Düzenli hayat eksikliği & 2 \\
Aidiyet duygusundan yoksunluk & 1 \\
Ailenin öğrenciye destek vermemesi & 1 \\
Başlangçta problem yaşama & 1 \\
Bazen yaşyorum & 2 \\
Hayır yaşamıyorum & 2 \\
\hline Toplam & $\mathbf{5 0}$ \\
\hline
\end{tabular}

Katılımcıların bazılarının doğrudan ifadeleri ise şu şekildedir: "Mutlaka farklı dilleri konuşmamı nedeniyle onlara kendimizi anlatmada ve onlar anlamada zorluklar yaşadık." (K4), "Yaşıyorum. Özellikle dil konusunda yaşanıyor. Bu konuda ögrencilerden yardım alıyorum." (K11), "Yaşamıyorum." (K35).

\section{"Yabancı Uyruklu Öğrencilerin Sorunları ile İlgili Yapılması Gerekenler Hususunda Önerileriniz Nelerdir?" Sorusuna Ait Bulgular}

Tablo 7. Yabancı Uyruklu Öğrencilerin Sorunları ile İlgili Önerilerin Değerlendirilmesi

\begin{tabular}{ll}
\hline Yabancı Uyruklu Öğrencilerin Sorunlarına Yönelik Çözüm Önerileri & f \\
\hline Ayrı bir sınıfta eğitim almaları & 17 \\
Önceden Türkçe öğretilmeli & 14 \\
Önceden okuma-yazma öğretilmeli & 8 \\
Velilere yetişkin eğitimi verilmeli & 4 \\
Kendi dillerinde eğitim almalılar & 4 \\
Uyum sınıfları açılmalı & 4 \\
Öğretmenlere bu konuda eğitim verilmeli & 3 \\
Farklı eğitim materyalleri tasarlanmalı & 2 \\
Okullara ve sınıflara bu öğrenciler eşit dağıtılmalı & 1 \\
Aidiyet duygusu sağlanmalı & 1 \\
Eksiklikler adım adım giderilmeli & 1 \\
Ülkelerine geri gitmeliler & 1 \\
\hline Toplam & $\mathbf{6 0}$ \\
\hline
\end{tabular}


Tablo 7 incelendiğinde yabancı uyruklu öğrencilerle ilgili problemlere yönelik olarak sınıf öğretmenleri 12 kategoride 60 farklı yanıt vermişlerdir. $\mathrm{Bu} 12$ kategoriden 8 tanesinde birden fazla öğretmenin verdiği benzer cevaplar yer almıştır. 4 tanesine ise sadece birer öğretmen yanıt vermiştir. Öğretmenlerden hemen hemen yarısı bu öğrencilerin farklı bir sınıfta okutulmaları gerektiğini ifade etmişlerdir. 14 sınıf öğretmeni ise bu sınıflara öğrenciler getirilmeden önce Türkçe öğretilmesi gerekliliğini vurgularken 8 tanesi önceden okuma-yazma öğretilmesi gerekliliği üzerinde durmuştur. 4'er adet öğretmen ise velilere yetişkin eğitiminin verilmesi gerekliliğini, kendi dillerinde eğitim almaları gerekliliği ile uyum sınıfları açılması gerekliliği üzerinde durmuşlardır. Bunların dışında; öğretmenlerin de eğitim alması gerektiğini belirten 3 öğretmen, farklı eğitim materyallerinin tasarlanması gerekliliğini belirten 2 öğretmen, okullara ve sınıflara bu öğrencilerin eşit dağıtılması gerekliliğinden söz eden 1 öğretmen, aidiyet duygusu kazandırılması gerekliliğini belirten 1 öğretmen, eksikliklerin adım adım giderilmesini gerekliliğini belirten 1 öğretmen ile ülkelerine geri gitmeleri gerektiğini belirten 1 öğretmen yer almaktadır. Katılımcıların bazılarının doğrudan ifadeleri şu şekildedir:

"Bu ögrencilerin kendilerine ait ayrt sinuflarda ve diline uygun eğitim almalart." (K5)

"Uyum sinıfları oluşturulmall, okuma yazma ve anlama çalı̧̧malarına yönelik eğitimler verilmeli. Velilere yönelik dil ve iletissime yönelik eğitimler verilmesinin faydalı olacağını düşünüyorum." (K11)

"Bence yabancı öğrenciler için ayrı bir sinıf veya il genelinde ayrı bir okul ortamı oluşturularak yabancı ögrencilerin dilini bilen ögretmenler görevlendirilirse yabancı uyruklu ögrenciler açısından daha verimli olacağını düşünüyorum. Bizim okulda 1. sinıfta 20'ye yakın öğrenci var. Bu ögrenciler için ayrı bir sinıf oluşturulursa daha verimli olur düşüncesindeyim." (K14)

"Hepsi bir sinıfa toplanıp ayrı bir program ile ögrenim görmeliler." (K16)

"Okula kaylt olur olmaz önce okuma yazma ve Türkçe ögrenebilecekleri bir yerde eğitim alırlarsa bize de daha hazır olarak gelmiş olurlar. Çünkü biz her yll tekrar ona okuma yazma ögreterek başlyyoruz ve bu da hep çocuğun geriden gelmesine neden oluyor." (K27)

"Birebir iliş̧i ve göz kontağı kurarak kendisini sınıfa ait hissetmesini sağlamak ve eksikliklerini adım adım gidermek." (K35) 


\section{Tartışma ve Sonuç}

Araştırmanın bulguları doğrultusunda çeşitli sonuçlara ulaşılmıştır. Öğretmenlerin sinıflarında en az 1 en fazla 5 olmak üzere yabancı uyruklu öğrenci mevcut olmasına rağmen öğretmenlerin bu öğrencilerle ilgili yeterli miktarda ya da hiç eğitim almadıkları tespit edilmiştir. Bu durumda öğretmenler yabancı uyruklu öğrenciler hususunda ortaya çıkan problemlerin çözümüne yönelik herhangi bir fikir yürütememesine neden olmaktadır. Öğrencilerinde herhangi bir eğitim sürecine dâhil olmadan eğitim kademesine doğrudan dâhil edilmesi ile çok ciddi bir dil, uyum ve iletişim sorunu ile karşı karşıya kaldıkları sonuçları ortaya çıkmaktadır. Kiremit, Akpınar ve Tüfekçi-Akcan (2018) tarafında yapılan çalışmada öğretmenlerin en büyük problemlerinin ise Suriyeli öğrenciler ile iletişim kuramamaları olduğunu belirtmişlerdir. Başar, Akan ve Çiftçi (2018) tarafından yapılan çalışmada dil sorunundan dolayı iletişim kuramamanın en büyük problem olduğunu tespit etmişlerdir. Bulut, Kanat-Soysal ve Gülçiçek (2018) tarafindan yapılan araştırmada anadili Türkçe olmayan öğrenciler karşısında öğretmenlerinde çözüm önerileri getirmekte zorlandıkları tespit edilmiştir. Dil problemi noktasında öğretmenlerin verdiği bulgular ışığında ki sonuçlarla bu çalışma örtüşmektedir.

Eğitim sistemine dâhil edilen bu öğrencilere yönelik olarak MEB tarafından herhangi bir çalışma yapılmadığ konusunda hemen hemen tüm öğretmenler aynı fikirdedirler. MEB'in kitaplarda, programlarda ya da etkinliklerde bir çalışma yapmaması sınıf öğretmenlerine yine problem olarak dönmektedir. Çünkü normal kitaplardaki etkinliklere, programa yabancı uyrukluları dâhil etme ile ilgili bir fikre ve çözüm önerisine sahip değillerdir. Kurumların düzenleme yapmaması ve herhangi bir öneride bulunmaması ile birlikte sınıf öğretenlerinin büyük bir bölümü de çözümsüz kalmaktan dolayı sınıflarında yabancı uyruklu öğrencilere yönelik olarak herhangi bir çalışma yapmamalarına neden olmaktadır. Göktuna-Yaylacı, Serpil ve Yaylacı (2017) tarafından yapılan çalışmada Suriyeli mülteci ve sığınmacılara yönelik eğitimde olumlu adımlar atıldığı ancak eğitim hizmetlerinin kalitesi, öğretmen yeterlikleri, eğitim etkinliklerini düzenleyen kurumlar arasındaki uyum problemleri ve araç-gereçler gibi konularda eksiklikler tespit edilmiştir. Araştırmanın sonuçları ile bu çalışmanın sonuçları eğitimde olumlu adımlar atılması noktasında örtüşmemektedir. Araştırma problemleri doğrultusunda öğretmenlere yöneltilen sorularda özeleştiriye açık sorular olmasına rağmen 4 ve 5 . alt probleme ait sorular bu çalışmada öğretmenlerin öz eleştiri yapmadıkları belirlenmiştir. 
Sınıf öğretmenleri velilerle de en az öğrenciler kadar dil ve iletişim problemi yaşamaktadırlar. Problem yaşamıyorum diyen öğretmen sayısı ise neredeyse yok denecek kadar azdır. Aykırı (2017) tarafından yapılan çalışmada Suriyeli öğrencilerin eğitimine yönelik olarak herhangi bir eğitim almadıkları, öğrencilerle olumlu ilişkiler kurarken velilerle olumsuz ilişkiler kurdukları belirtilmiştir. Öğretmenlerin eğitim almamaları noktasında çalışma ile bu çalışmanın sonuçları örtüşmektedir. Öğrencilerle olumlu ilişki kurmada ise çalışmaların sonuçları birbirini desteklememektedir.

Öğretmenlerin yabancı uyruklu öğrenciler ile ilgili çözüm önerileri değerlendirildiğinde ise dikkat çekici nokta öğretmenler bu öğrencilere ayrı sınıf açılması gerektiğidir. Bu da öğrencileri özellikle Türkçe bilmeden sınıflarında istemediklerinin göstergesidir. Çok sayıda çözüm önerisi içerisinde en dikkat çekici nokta ise önerilerin hemen hemen hepsinin öğrencilere ve MEB'e yönelik olmasıdır. Öğretmenlerle ilgili sadece 3 kişinin öneride bulunmuş olması öğretmenlerin özeleştiriden uzak olduklarının göstergesi olarak değerlendirebilir.

Yavuz ve Mızrak (2016) tarafından yapılan çalışmada Türkiye'de mültecilerin eğitimi için pek çok desteğin verildiğini ancak yeterli sayıda çocuğun bu eğitim firsatlarından yararlanamadıklarını belirlemişlerdir. Bunun nedeni olarak ise fakirlik ve geçerliği olan diplomaların verilmemesi gösterilmektedir. Bu sorunların çözümü için ise hükümetler, uluslararası kuruluşlar ve sivil toplum kuruluşları arasındaki iş birliğinin artırılması gerektiğini ifade etmişlerdir. Araştırma bulguları içinde az sayıda da olsa yer alan maddi yetersizlik ile bu çalışmanın bulguları örtüşmektedir.

\section{Öneriler}

$\mathrm{Bu}$ sonuçlar doğrultusunda yabancı uyruklu öğrencilere yönelik olarak şu öneriler getirilebilir:

- Öğretmenlere yabancı uyruklu öğrencilerle ilgili daha uzun süreli ve sürekli güncellenen eğitimler verilebilir. Öğretmenlerin yabanc1 uyruklu öğrencilerin eğitim-öğretim ortamlarını düzenlemeye yönelik herhangi bir şey yapmadıklarını belirtmelerinden dolayı öğretmenlerin aldıkları eğitimleri alanda uygulanıp uygulamadıklarının denetlenmesi gerekmektedir.

- MEB yabancı uyruklu öğrencilere yönelik olarak ayrı programlar tasarlayıp, etkinlikler belirlemeli ve böylece öğretmene alternatifler sunmalidir. 
- Yabancı uyruklu öğrencilere dil problemini çözmek amacı ile uyum s1nıfları açılmıştır. Ancak uyum sınıflarında sadece dil değil diğer bütün yaşanabilecek problemlerle ilgili uyum sürecine dâhil edilebilir.

- Yabancı uyruklu öğrencilerin velileri ile iletişim noktasında sadece öğretmene değil velilere de iş düşmektedir. Bu noktada velilere mutlaka yetişkin eğitimi verilip ülkemizin eğitim sistemi ayrıntılı açıklanmalı ve sürekli iletilişim içinde olunmalıdır.

\section{Kaynakça}

Afet ve Acil Durum Yönetimi Başkanlığı (AFAD) (2017). Suriye afet raporu. https://www.afad.gov.tr/tr/2373/Giris

Ar1, Ş. (2010). Kuzey Kıbrıs Türk Cumhuriyeti'nde ilköğretimin ikinci kademesinde ögrenim gören yabancllara Türkçe öğretimi üzerine bir değerlendirme. Yayımlanmamış doktora tezi, Gazi Üniversitesi Eğitim Bilimleri Enstitüsü.

Aykırı, K. (2017). Sınıf öğretmenlerinin sınıflarındaki Suriyeli öğrencilerin eğitim durumlarına ilişkin görüşleri. Turkish Journal of Primary Education, 2(1), 4456.

Başak, C. (2011). Mülteciler, sı̆̆ınmacılar ve yasadışı göçmenler. Ankara: Sonsöz Matbaacilik.

Başar, M., Akan, D. ve Çiftçi, M. (2018). Mülteci öğrencilerin bulunduğu sınıflarda öğrenme sürecinde karşılaşılan sorunlar. Kastamonu Eğitim Dergisi, 26(5), 1571-1578.

Berg, B. L. ve Lune, H. (2015). İçerik analizine giriş. (Z. E. Özcan, Çev.). H. Aydın, (Çev. Ed.), Sosyal bilimlerde nitel araştırma yöntemleri içinde (17-36). Konya: Eğitim Yayınevi. (Orijinal çalışma basım tarihi 2012.)

Bulut, S., Soysal, Ö. K. ve Gülçiçek, D. (2018). Suriyeli öğrencilerin Türkçe öğretmeni olmak: Suriyeli öğrencilerin eğitiminde karşılaşılan sorunlar. Uluslararası Türkçe Edebiyat Kültür Eğitim Dergisi, 7(2), 1210-1238.

Boyraz, Z. (2015). Türkiye'de göçmen sorununa örnek Suriyeli mülteciler. Zeitschrift für die Welt der Türken/Journal of World of Turks, 7(2), 35-58.

Büyüköztürk, Ş., Çakmak, E., Akgün, Ö., Karadeniz, Ş. ve Demirel, F. (2009). Bilimsel araştırma yöntemleri. Ankara: Pegem Akademi.

Ciğerci, M. ve Güngör, F. (2016). The problems encountered by the foreign primary school students from the perspectives of classroom teachers (Bilecik sampling). Journal of Education and Future, 10, 137-164.

Creswell, J. W. (2013). Beş nitel araştırma yaklaşımı. (M. Aydın, Çev.). M. Bütün ve S. B. Demir, (Çev. Ed.), Nitel araştırma yöntemleri: beş yaklaşıma göre nitel araştırma ve araştırma deseni içinde (69-110). Ankara: Siyasal Kitabevi. (Orijinal çalışma basım tarihi 2012.)

Dinçer, O. B., Karaca, S. ve Yavuz, H. (2013). Göçün ikinci yılında Suriyeli savaş mağdurlar. Analist Dergisi, 25.

https://www.academia.edu/6893326/G\%C3\%B6\%C3\%A7\%C3\%BCn_\%C4

$\%$ B0kinci Y\%C4\%B11\%C4\%B1nda Suriyeli Sava\%C5\%9F Ma\%C $4 \% 9 \mathrm{Fd}$ urlar $\% \mathrm{C} 4 \% \mathrm{~B} 1$

Çalık, T. ve Sezgin, F. (2005). Küreselleşme, bilgi toplumu ve eğitim. Kastamonu 
Eğitim Dergisi, 7(20), 441-453.

Er, O., Biçer, N. ve Bozkırlı, K. Ç. (2012). Yabancılara Türkçe öğretiminde karşılaş1lan sorunların ilgili alan yazını ışığında değerlendirilmesi. Uluslararası Türkçe Edebiyat Kültür Eğitim Dergisi, 1, 51-69.

Göktuna-Yaylacı, F., Serpil, H. ve Yaylacı, A. F. (2017). Paydaşların gözünden mülteci ve sığınmacılarda eğitim: Eskişehir örneği. Akdeniz Eğitim Araştırmaları Dergisi, 22, 101-117.

Güngör, F. ve Şenel, E. A. (2015). Yabancı uyruklu ilkokul öğrencilerinin eğitimögretiminde yaşanan sorunlara ilişkin öğretmen ve öğrenci görüşleri. Yayımlanmamış yüksek lisans tezi, Anadolu Üniversitesi Eğitim Fakültesi.

Gürle, N. Ş. (2012). İstanbul'da refakatsiz sığınma ve mülteci çocukların karşılaştıkları sorunlar ve uygulamalar. Yayımlanmamış yüksek lisans tezi, İstanbul Üniversitesi Sosyal Bilimler Enstitüsü.

Kaştan, Y. (2015). Türkiye'de göç yaşamış çocukların eğitim sürecinde karşılaşılan problemler. Uluslararası Sosyal ve Eğitim Bilimleri Dergisi, 2(4), 216-229.

Kılınç, E. (2014). Antalya'da yaşayan yabancı uyruklu aile çocuklarının karşılaştığ ĕgitim sorunları (Uluslararası Özel Antalya Rus Okulu Örneği). Yayımlanmamış yüksek lisans tezi, Akdeniz Üniversitesi Eğitim Bilimleri Enstitüsü.

Kiremit, R. F., Akpınar, Ü. ve Tüfekci-Akcan, A. (2018). Suriyeli öğrencilerin okula uyumları hakkında öğretmen görüşleri. Kastamonu Education Journal, 26(6), 2139-2149.

Mayring, P. (2014). Qualitative content analysis. Theoretical foundation, basic procedures and software solution.

https://nbn-resolving.org/urn:nbn:de:0168-ssoar-395173

MEB (2014). Yabancllara yönelik eğitim-öğretim hizmetleri.

http://mevzuat.meb.gov.tr/dosyalar/1715.pdf

MEB (2018). Geçici koruma kapsamı altındaki öğrencilerin ĕgitim Hizmetleri. https://hbogm.meb.gov.tr/meb_iys_dosyalar/2018_05/23115755_21-052018 Ynternet_BYlteni.pdf

MEB (2019). Yabancı ögrenciler uyum sinıfi. http://mevzuat.meb.gov.tr/dosyalar/2022.pdf

Miles, M. B. ve Huberman, A. M. (2015). Analizde İlk Adımlar. (A. Ersoy, Çev.). S. Akbaba-Altun ve A. Ersoy, (Çev. Ed.), Nitel veri analizi içinde (50-89). Ankara: Pegem Akademi. Orijinal çalışma basım tarihi 1994.)

Moustakas, C. (1994). Phenomenological research methods. Thousand Oaks, CA:Sage Publishers.

Özdemir, S. M, Benzer, H. ve Akbaş, O. (2009). Almanya'da yaşayan 15-19 yaş Türk gençlerinin eğitim sorunlarına ilişkin bir inceleme (Kuzey Ren Vestfalya Örneği). Ahi Evran Üniversitesi Kırşehir Eğitim Fakültesi Dergisi (KEFAD), 10(1), 23-40.

Özer, Y. Y., Komşuoğlu, A. ve Ateşok, Z. Ö. (2016). Türkiye'deki Suriyeli çocukların eğitimi: sorunlar ve çözüm önerileri. Akademik Sosyal Araştırmalar Dergisi, 4(37), 34-42.

Patton, M. (1990). Qualitative evaluation and research methods. BeverlyHills, CA: Sage Publications.

Polat, F. (2012). Türkiye'de ögrenim gören yabancı uyruklu ilköğretim öğrencilerinin karşılaştıkları sorunlar ve çözüm önerileri. Yayımlanmamış yüksek lisans tezi, 
Fırat Üniversitesi Eğitim Bilimleri Enstitüsü.

Sarıtaş, E., Şahin, Ü. ve Çatalbaş, G. (2016). İlkokullarda yabancı uyruklu öğrencilerle karşılaşılan sorunlar. Pamukkale Üniversitesi Sosyal Bilimler Enstitüsü Dergisi, 25(1), 208-229.

Seydi, A. R. (2013). Türkiye'deki Suriyeli akademisyen ve eğitimcilerin görüşlerine göre Suriye'deki çatışmaların Suriyelilerin eğitim sürecine yansımaları. Süleyman Demirel Üniversitesi Fen-Edebiyat Fakültesi Sosyal Bilimler Dergisi, 30, 2017-241.

Sezik, M. ve Ağır, Ö. (2015). Suriye'den Türkiye'ye yaşanan göç dalgasından kaynaklanan güvenlik sorunları. Birey ve Toplum Sosyal Bilimler Dergisi, 5(1), 95-124.

Şahin, C. (2001). Yurt dışı göçün bireyin psikolojik sağlığı üzerindeki etkisine ilişkin kuramsal bir inceleme. Gazi Üniversitesi Gazi Eğitim Fakültesi Dergisi, 21(2), 57-67.

Şimşir, Z. ve Dilmaç, B. (2018). Yabanc1 uyruklu öğrencilerin eğitim gördüğü okullarda öğretmenlerin karşılaştı̆̆ı sorunlar ve çözüm önerileri. İlköğretim Online, $17(2), 1719-1737$.

Tanrıkulu, F. (2017). Türkiye'de yaşayan Suriyeli çocukların eğitim sorunu ve çözüm önerileri. Liberal Düşünce Dergisi, 22(86), 127-144.

T.C. İçişleri Bakanlığı, (2017). 2016 Türkiye Göç Raporu, Göç İdaresi Genel Müdürlüğ̈̈ Yayınları, Yayın No: 40, https://www.goc.gov.tr/kurumlar/goc.gov.tr/files/2016_yiik_goc_raporu_haziran.pdf

Uluocak, G. P. (2009). İç göç yaşamış ve yaşamamış çocukların okulda uyumu. Dokuz Eylül Üniversitesi Buca Ĕ̈itim Fakültesi Dergisi, 26, 35-44.

United Nations International Children's Emergency Fund (UNICEF). (2016). Türkiye'deki Suriyeli çocuklar. file://C:/Users/pc/Desktop/5b27be547.pdf

Uyar, Y. (2007). Türkçe öğretiminde kültür aktarımı ve kültürel kimlik geliştirme. Yayımlanmamış yüksek lisans tezi, Gazi Üniversitesi Eğitim Bilimleri Enstitüsü.

Yapıc1, M. ve Yapıc1, Ş. (2003). İlköğretim öğretmenlerinin karşılaştığı sorunlar. Bilim, Eğitim ve Düşünce Dergisi, 3(3), 1-9.

Yavuz, Ö. ve Mızrak, S. (2016). Acil durumlarda okul çağındaki çocukların eğitimi: Türkiye'deki Suriyeli mülteciler örneği. Göç Dergisi, 3(2), 175-199.

Yıldırım, A. ve Şimşek, H. (2006). Sosyal bilimlerde nitel araştırma yöntemleri. Ankara: Seçkin Yayıncılık. 